\title{
The Political and Historical Representation of Statues in Three Ethiopian Consecutive Regimes (1889 - Present)
}

\author{
Mulualem Daba Tola \\ Department Public Relation and Strategic Communication, College of Social Sciences and Humanities, Wolaita Sodo University, Wolaita \\ Sodo, Ethiopia
}

Email address:

mulelikeu11@gmail.com

\section{To cite this article:}

Mulualem Daba Tola. The Political and Historical Representation of Statues in Three Ethiopian Consecutive Regimes (1889 - Present). Social Sciences. Vol. 6, No. 2, 2017, pp. 35-44. doi: 10.11648/j.ss.20170602.11

Received: January 16, 2017; Accepted: February 29, 2017; Published: March 27, 2017

\begin{abstract}
Statues are symbols which represent dynamic societal values. They serve as a rallying point for shared common memory and identity and, hence, are used as a collective remembrance. They also have a power to immortalize an intended ideology. Statue is an object that represents the religion, history, culture, art, socio- economic and political practices of one nation. The main purpose of this paper is to describe the political representation of iconic statues erected in three, Imperial monarchy, Derg Military Junta and Ethiopian People's Revolutionary Democratic Front (EPRDF) regimes in Ethiopia. To achieve this purpose, several documents from Culture and Tourism Bureaus and library archives are analyzed qualitatively. The study lastly summarizes the erected statues in the three Ethiopia regimes are highly tied with the political manifesto each regime. In the process of political shift, when the former regime replaced by the new one, simultaneously, the former statues are dismantled and dislocated and the new statues that represents the current political ideology are constructed and replaced. Accordingly, it concluded that, statues represent the political context of these three consecutive regimes in Ethiopian polity.
\end{abstract}

Keywords: Ethiopia, Historical, Political, Statue, Representation, Identity

\section{Introduction}

Statues have been erected for thousands of years for different purposes, and they are often the most durable and famous symbols of ancient civilizations. In ancient civilization of Egypt, Mesopotamia, Indus valley, and China, people made statues to provide spiritual activities. For instance, Egyptians erected statues for the rulers and nobles on pyramids believing that the spirit of dead could always return to these images. Similarly, in the ancient Mesopotamia the colossal form of the king mighty and majesty statues were built at the entrances of their palaces as guardian monster-five legged winged bulls with human heads. In the Aegean civilization, the statue of lion also served as a protector of fortified Mycenae city where the king Agamemnon supposed to live. In addition, in Rome around $12^{\text {th }} \mathrm{C}$ (early Christian age), statue served as idols (false god) that was regarded as a breach of the commandments (Harrt, 1989, Jonson, 1966, Whelan, et. al, 2002).

In the renaissance period, statues were used to represent people's ideas or concepts. They are used to show the aesthetic value of the world and enlightenment ideology. The pioneers of this period like Donatello, Pisano and others work of statue represent human feelings of beauty and liberation from Dark Age. In the $19^{\text {th }} \mathrm{C}$ and early $20^{\text {th }} \mathrm{C}$, statues are also often erected to represent historical phenomena or political ideologies. Sculptors use their art making of statue to reinforce the primacy of contemporary political power. For instance, numerous statues of Lenin are crafted in the Soviet Union and in other alliance countries to strength the socialist ideology. Similarly, throughout Europe and North America statues from late $18^{\text {th }} \mathrm{C}$ until the beginning of $19^{\text {th }} \mathrm{C}$ several statues were erected for social and political purposes (Harrt, 1989; Whelan, 2002).

In Africa, statues are erected intend to represent several social values. In the pre-colonial era, statues are curved for religious ceremony and to honor their ancestor and kings. During the period of colonization, the statues of colonizers were erected in several African countries to legitimize their political and economical upper hand. For instance, the Queen 
Victoria statue, and the two King George V statues were erected in Kenya for British monarchs during colonization period (Larsen, 2013). Voortrekkers monument was also erected for Voortrekkers in South Africa who colonized the interior of South Africa (Grundlingh, 2001). Most of statues constructed in Africa during the period of colonization are dismantled or replaced after African countries got their independency (Duerksen, 2012 and Dresser, 2007)

Among African countries, Ethiopia has long history of civilization in terms of architectural art. Since the heyday of Aksumite period $\left(4^{\text {th }} \mathrm{C}-7^{\text {th }} \mathrm{C}\right.$ A. D.) different obelisk, edifices, rock-hewn churches and monoliths were curved as kings' home, funeral or for religious purposes. For instance, the Axum obelisk which was erected around $4^{\text {th }} \mathrm{C}$ A. D by subjects of the kingdom of Aksum, Tiya monuments and the largest edifice 'Ta'akha Maryam' were taken as one of Ethiopian ancient architectural civilizations. Predominantly, various historical statues mostly found in the highland parts of Ethiopia due to different kingdoms are emerged along with the acceptance of Orthodox religion. Thus, the tradition of erecting monuments has an age-old history in Ethiopia (Doresse, 1959; Pankhurst, 1982; Finneran, et.al, 2012).

The present Ethiopia has passed through three regimes from Monarchial period to the FDRE (Federal Democratic Republic of Ethiopia). These are the imperial monarchy particularly from the reign of Emperor Tewdros II to Emperor Haile Silasse I (1855-1974), the Derg regime which subscribed to socialism (1974-1991) and the EPRDF (Ethiopian People's Revolutionary Democratic Front) regime which advocates multiparty democracy (1991-present). However, the history of modern Ethiopia begins specifically from the period of Emperor Menelik II (1889-1913) (Bahru, 1991, 1994 \&2001; Marcus, 1994; Merera, 2003; Turton, et.al, 2006). In these three consecutive regimes, different monuments have been erected to represent the country's history, culture, political and even statues of famous individuals from inside and outside Ethiopia are constructed to dedicate their contribution they made for Ethiopia at different historical junctures. However, it is difficult to overview all monuments erected in Ethiopia. Due to this, this paper is limited to well-known statues constructed in three Ethiopian consecutive regimes. Besides, the review particularly starts from statues constructed in the reign of Menelik II (1889-1913 due to the reign of Emperor Menelik II was the beginning of modern Ethiopian history (Turton, 2006; Aalen, 2002; Sorenson, et. al, 1993). Thus, the main aim of this paper is to review and analyze the political representations of famous statues erected only in three (Imperial monarch, Military junta, Development Democracy) regimes.

\section{Rationale}

Societies often erect statues to represent their culture, religion and various societal values. Several scholars also wrote series of papers on various aspects of statues symbolism. There are also scholars, for instance, Dresser
(2007); Whelan (2001); Larsen (2013); Gavua (2011); Grundlingh (2001) and others investigated the representation of statue from political point of view. However, in Ethiopian context, a few scholars wrote particularly on the historical narratives and the cultural values of statues erected in Ethiopia. Others also examine status' architectural design in relation with the civilization of Ethiopian societies. Despite the fact that construction of statues not only in Ethiopia, but also across the world is interwoven with politics, a little is known and explicitly investigated the political representation of iconic statues constructed in Ethiopia in three consecutive political regimes. There is no academic research examines the political representation of iconic statues constructed starting from the modern Ethiopian history (1889). Therefore, this paper would make available a body of knowledge on the statues and their political representation in Ethiopia at different political juncture. Besides, this paper can be used as a spring board for other researchers who are interested to investigate more.

\section{Objective}

Statues have constructed in Ethiopia since $14^{\text {th }} \mathrm{C}$ which is the period of Axumite civilization. During this period, statues were constructed primarily for the fulfillment of spiritual practices. However, since the period of modern Ethiopian history which account from the period Emperor Menelik II (1889) statues were constructed to legitimize the authority of emperors at different time. Since then the construction of statue in Ethiopia more inclined towards serving the political ideology. Hence, the main purpose of this paper is to describe the political representations of statue constructed in three (Imperial monarchy, Derg the military junta, and EPRDF the multi party system) regimes in Ethiopia.

\section{Method and Methodology}

Descriptive research design is used to analyze the political representation of iconic statues erected in three consecutive regimes in Ethiopia. The statues are purposively selected depending on their well-known historically grounded narratives and predominantly found in the capital Addis Ababa. This is due to the setting the capital Addis Ababa was the first Emperors city and as a result different architectural works and most of iconic statues were constructed in the capital. Different documents from Culture and Tourism office, Addis Ababa City Governance, library archives and several literatures are used as to get the relevant information. The gathered data are analyzed by qualitative research approach method.

\section{Discussion}

The purpose of this paper is to analyze the political representation of statues mainly constructed in the capital Addis Ababa in the three consecutive regimes (Imperial monarchy, Derg Military Junta and Federal Democratic 
republic of Ethiopia). To achieve this purpose, several documents and articles are reviewed and analyzed. The analyzed data are discussed under three main sub-topics below.

\subsection{Monarchial Period (Emperor Menelik II - Haile Silasse I)}

The monarchial regime refers to the period from the reign of Emperor Menelik II to Haile Silassie I (1889-1974) in the modern Ethiopian history. Menelik II of Showa came to power and proclaimed himself as Nigusa Negist (king of kings) in 1889. Then he pursued his imperial policies of modernization and centralization. He undertook series of military conquests to expand his territory particularly to the southern and western parts of the country. On the other hand, in order to modernize the country, the Emperor introduced different modern technologies and built infrastructures. Besides, the Emperor gained a historic victory over Fascist Italy in defending the Ethiopian territory from colonization, and this victory has even been considered as African (Black) victory. During his reign, Emperor Menelik II benefited his Showa forebears economically, politically and the AmharaTigre culture subsequently became superior while other ethnic groups were ignored and subjected to assimilation (Bahru, 1991; McClellan, 1978; Marcus, et.al, 1994).

After the death of Menelik II, Lij Iyasu (1913-1916) with Princess Zewditu ruled the country till Ras Tafari Mekonnen officially came to power in 1928. Ras Tafari Mekonnen took his baptismal name Haile Silasse I in 1930 at the largest coronation ceremony ever seen in the history of Ethiopia. During the reign of Haile Silasse I (1930-1974), no shift of political ideology took place. He walked in the footprints of his predecessor and continued the centralization and modernization policy of Emperor Menelik II. As a result, the landed aristocracy and the majority of peasants constituted the major socio-economic agents. $\mathrm{He}$ initiated the establishment of a modern cash crop economy and the expansion of the educational system. In 1931, the first written constitution of the country which neither included provisions of civil liberties nor established a representative legislature was introduced to simply consolidate the Emperor's power. However, the emperor played a crucial role in calling for a united Africa and in the establishment of the then Organization of the African Unity (OAU)-the now African Union- in 1960s (Marcus, 1994; Alamayo, 1901; Greenfield, 1965; Bahru, et.al 1991).

However, Hailesilasse's unwillingness and incapability to respond to social movement, his refusal to land reform, and lack of willingness for transition to modern economy, and autocratic style of governance were among the major problems during his reign. Peasant rebellions and ethnically based liberations in different parts of the country and a largescale famine in the north parts of the country exacerbated the problems associated with the reign of Emperor Hailesilasse I. Besides, the demonstrations of students, civil servants and mutinies in the armed forces, and Bale and Gojjam farmer's rebellion accelerated the deposition of the Emperor and the coming to power of a military junta (Greenfield, 1965; Aalen, 2002; Bahru, 1991; Marcus, et.al, 1994).

In the period of Imperial Monarchy, different statues were constructed by the feudal aristocrats for the purpose of reinforcing their economic and political dominance over the majority peasants. Since emperor Menelik II found Addis Ababa in 1887, different architectural works such as the palace of the Emperor and various edifices were built by foreign architects from India, Greek and Italia (Pankhurst, 1982). Thus, the history of constructing different sizes of statues in the capital is estimated from the reign of Menelik II. However, the erection of well-standardized monuments took place when Emperor Haile Silasse I came to power. The known statues erected the period of imperial Monarchy are discussed below.

\section{The Statue of Lion of Judah}

There are two iconic and historically grounded statues of the lion of Judah in the capital Addis Ababa. The first was erected at the square of the Addis Ababa railway station with the help of Menelik's II Swiss advisor, then foreign Minister, Engineer Alfred Lig. The statue was built to show the devotion of Emperor Menelik II to link Ethiopia with the outside world by means of the railway line. The statue consisted pictures of emperor Menelik II, Haile Selassie, Ras Mekonen and Princess Zewditu. This statue was looted in 1935 by the fascist Italian from Ethiopia and erected in Italy next to the Vittorio Emanuelle monument. However, after long negotiations in the 1960's the statue of lion of Judah finally returned and re- erected around Ethio - Djibouti Railways in the capital Addis Ababa (Mirror of Addis Ababa, 1950; Pankrust, 1998 and Bahru, 1992).

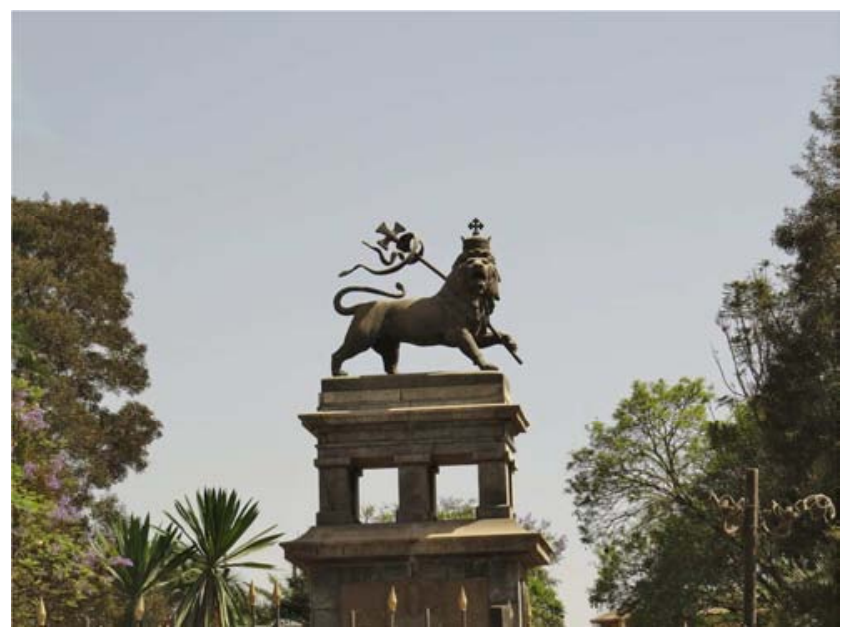

Figure 1. Statue of Lion of Judah at Ethio - Djibouti.

The second statue of the lion Judah which sometimes called "Lion of Haile Silasse I" was found around National Theatre on the western side of Unity Square. It was designed and built by French sculptor Morris Calka, the winner of grand Prix of Rome to commemorate the $25^{\text {th }}$ Silver Jubilee of Emperor Haile Selassie celebrated in 1955 (Addis Ababa City of Government, Office of the Mayor, 2011/12). The symbol of the statue served as a logo to the former Ethiopian 
Tourism Commission and is still serving the present Ministry of Culture and Tourism, depicting the country's tourism promotion slogan 'Thirteen Months of Sunshine' (Addis Ababa city Administration, 2009).

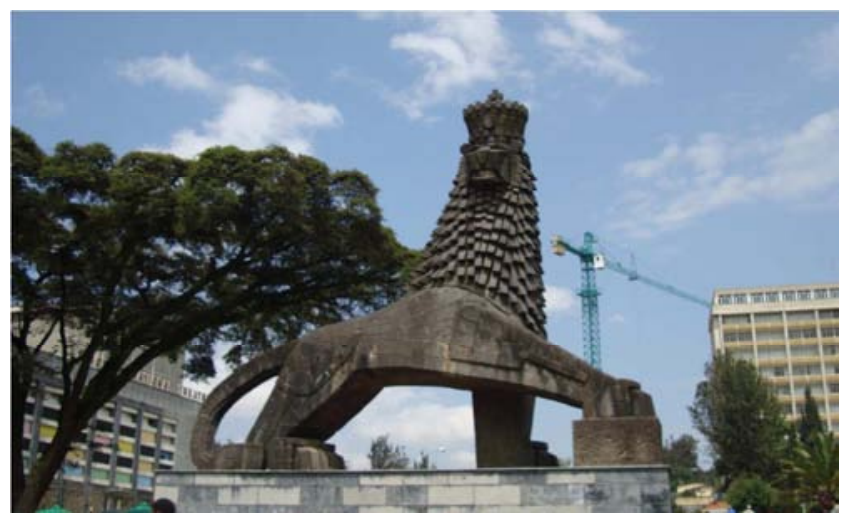

Figure 2. The Sataue of Lion of Judah infront of National Theater.

In the Ethiopia monarchial era, the symbol of Lion of Judah was ubiquitous throughout the country. The lion is the symbol of heroism and resistance to Ethiopians. During this period, especially, the lion was the icon of the imperial dignity. In this way, these statues were serving to strengthen and legitimize the emperors' power.

II. Freedom (Victory) Statue or 'Miyazya 27'

Freedom (Victory) statue is commonly known as 'Miyazya 27' among Ethiopians. The statue was erected for remembrance of Ethiopian patriots' victory over the Italian colonist in 1941. His imperial majesty Haile Silasse inaugurated this statue in 1944 in Miyazya 27 (May 04). The official name 'Miyazya 27' was the day of the liberation of the country and the arrival of the emperor together with his patriotic troops in Addis Ababa. The statue is found at Arat kilo in front of the Ethiopia Ministry of Education in the capital Addis Ababa (Mirror of Addis Ababa, 1950 and Addis Ababa city administration, 2009).

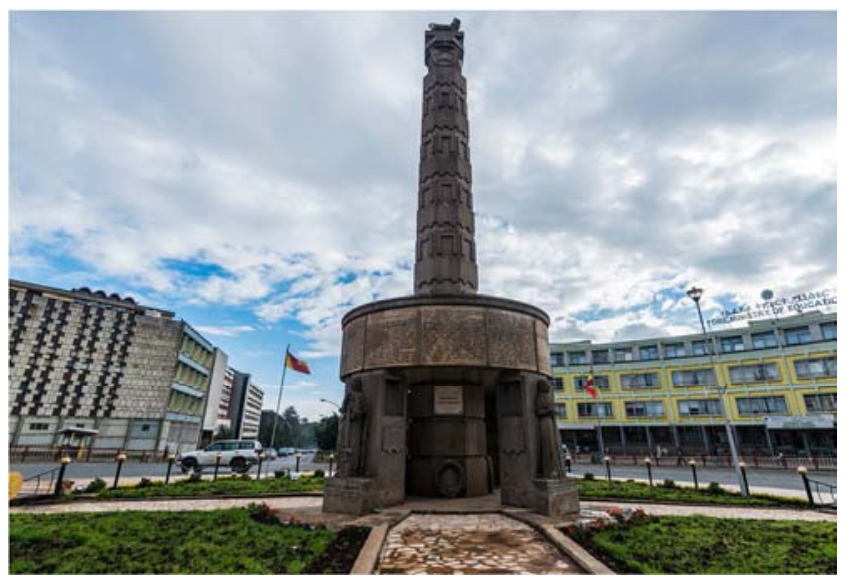

Figure 3. Statue of Victory (Freedom) or Miazya 27 at Arat kilo.

The $15 \mathrm{~m}$ height statue has six entrances and the history of the five-year struggle of Ethiopians to oust fascist Italy is narrated on carved stone around the statue. On the western entrance, there is a speech of Emperor Haile Selassie at the time of arrival and the day of liberation in 1941. On the north-west and north-East of the monument, there is a writing that commemorates the patriots of the five years struggle that depicted by the woman with bas- relief holding a sward in her hands. There is also the stone writing that narrates the contribution of gallant fighters who fought the enemy secretly at home submitting information to the patriots. On South-East of the statue, there is an image of Emperor Haile Selassie holding the Ethiopian flag, and the stone writings under the image narrates the great political and diplomatic role of the emperor to liberate the country. On South-west part of the monument, there is stone writing that narrates the role of Diasporas who fought against the fascist Italians' occupation.

Moreover, on the top of the statue, there is an image of Lion of Judah holding the Ethiopian flag facing the north direction and there is a clock indicating one o'clock to show the time of arrival of the patriots in Addis Ababa. The image of emperor Haile Silasse holding Ethiopian flag on victory monument was altered and changed to guerrilla fighter holding the flag during the Derg regime. However, it has restored to its original in the period of Federal Democratic Republic of Ethiopia (FDRE) (Addis Ababa City Administration, 2009)

\section{Martyrs' or 'Yekatit 12' Statue}

Martyrs' statue was erected in 1937 for commemoration more than 30,000 innocent people of Addis Ababa who massacred in three days by the order of fascist Italy leader Graziani in 'Yekatit 12' 1929 E. C' (February 19, 1937 G. C.). This cold blood massacre took place due to the attempt made to kill Viceroy Graziani by two young brothers, Moges Asgedom and Abraham Deboch. The statue was erected by two Yugoslavia architects namely Agostinchi Anto and Curcinich Fran. It was inaugurated on 19 February 1942 (Addis Ababa City Administration, 2009).

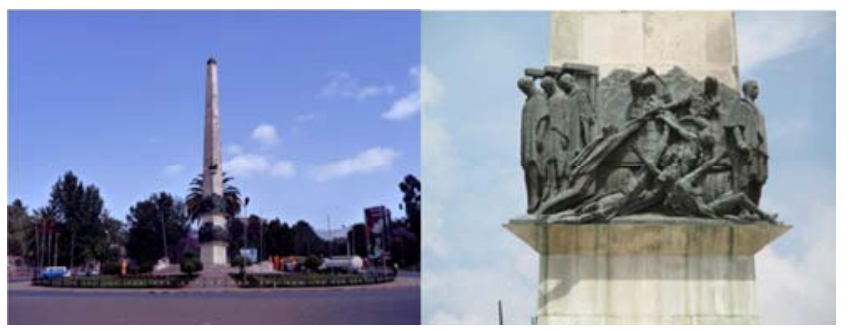

Figure 4. Martrys' or Yekatit 12 Statue.

\section{The Equestrian Statue of Menelik II}

The imposing equestrian statue of Emperor Menelik II was erected for the commemoration of battle of Adwa (1896) which is regarded as historic battle of black Africans. The statue stands in front of Genete Tsige Menagesha St. George church. The statue was built by German architect Hertel Spengel after 34 years later of the battle of Adowa and inaugurated by Emperor Haile Selassie on the day before his coronation $2^{\text {nd }}$ November 1930 (Mirror of Addis Ababa, 1950 and Addis Ababa city administration, 2009). 


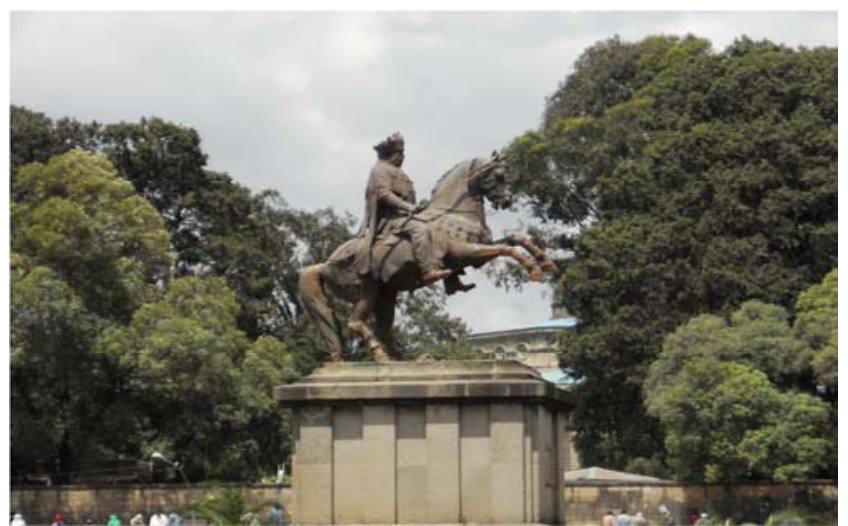

Figure 5. An Equestrian Statue of Emperor Menelik II.

The statue portrays Emperor Menelik in his coronation robes riding glamorously on his horse Abba Dagnew looking to the north where the victorious battle of Adwa took place.

\section{$V$. The Statue of His Holiness Abune Petros}

The Archbishop Abune Petros was one of the first Ethiopian Orthodox Church bishops from Wello who strongly supported Ethiopian patriots fighting with Italian forces. The Italian leaders tried many times to persuade Archbishop Abune Petros in order to preach gallant Ethiopian fighters to accept the Italian leadership. However, the Archbishop courageously faced the firing squad in defiance of the fascists and agitated both the patriots and the whole people not surrender to the Italians through excommunicating not only the faithful but also the land itself. As a result, His Holiness Abune Petros was shot by fascist Italians.

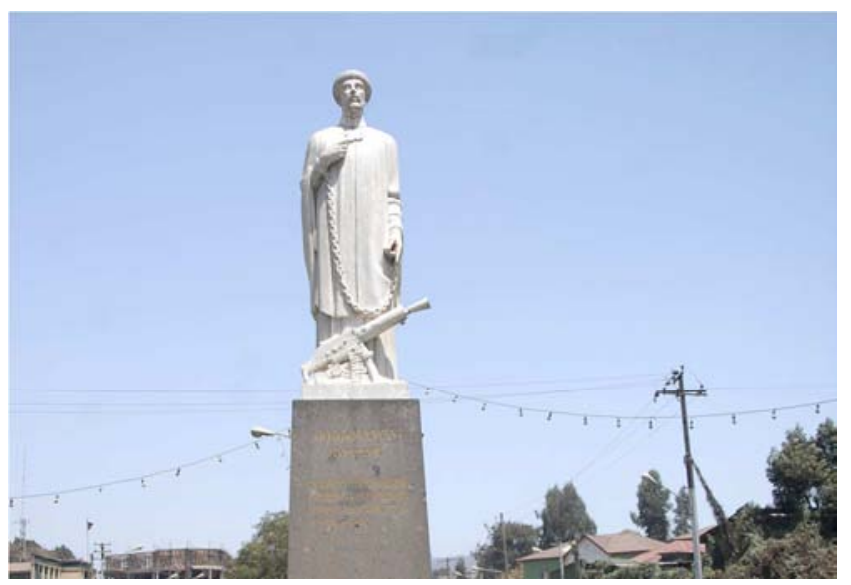

Figure 6. The Statue of Archbishop Abune Petros.

The 9.3 tone statue of his holiness Abune Petros was erected after the liberation in 1941 by Greek sculptor G. Georakas at west of Addis Ababa City Hall in front of the place of his martyrdom. The original statue was decorated with full bishopric robe, a cross and a bible in his hands; however, later it was replaced by guns with chained hands to indicate the action of his murder (Mirror of Addis Ababa, 1950 and Bahru, 1992).

VI. The Statue of Ras Mokenen Wolde Michael
Ras Mokenen Wolde Michael was a Governer of Harar and the right-hand General of Emperor Menelik II until his death in1906. His statue was built on the foundation laid near Ras Makonnen bridge by his son emperor Haile Selassie in 1931. However, when the Italians controlled Addis Ababa, the statue was dismantled. After the end of Italian occupation, the statue was curved again and inaugurated on May 5, 1934 (Bahiru, 1991\& 1992)

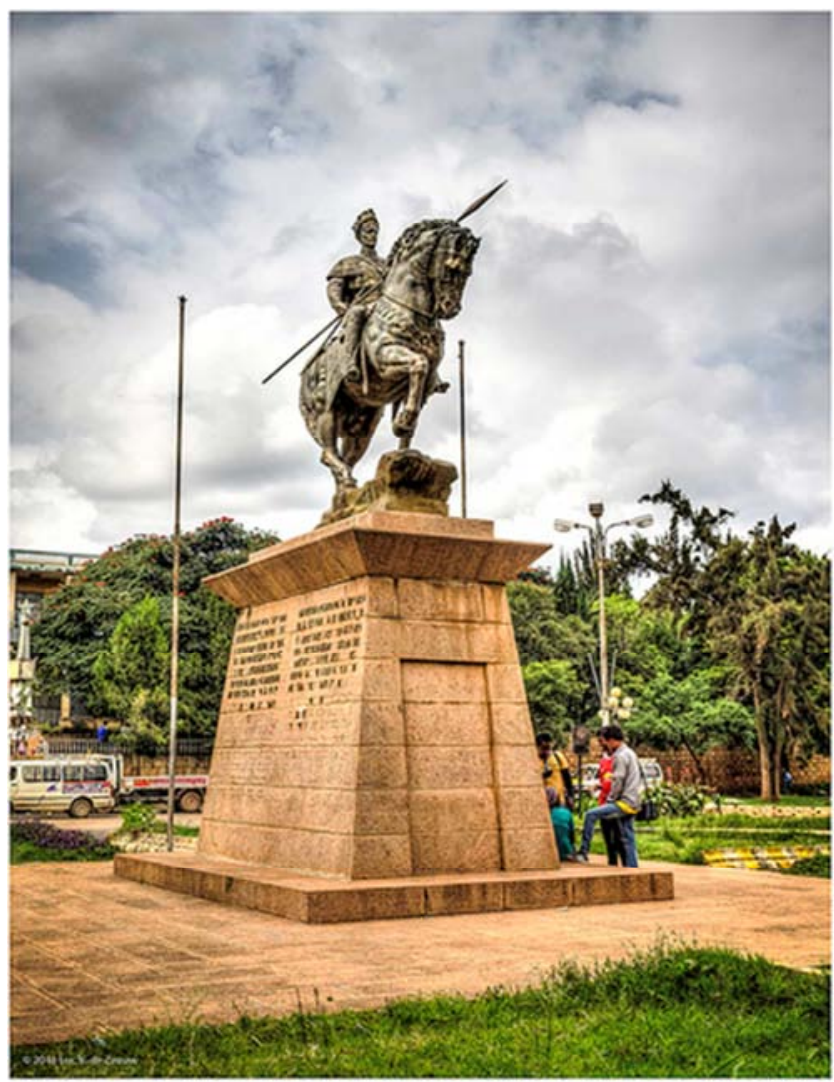

Figure 7. The statue of Ras Mokonen Wolde.

To conclude, the statues erected in Imperial Monarchy regime encompass two themes. First, they had tendencies of honoring or legitimizing the emperors' power in the political landscape. With this regard, for instance, the two lion of Judah statues were the first constructed statues during the reign of Haile silasse $I$ in the capital. On one hand, they were erected to commemorate the contribution of emperor Menelik II which implicitly shows the continuation of political system of emperor Menelik II. On the other hand, they were constructed to legitimize the power of Emperor Haile Silasse I through creating common visual narratives over the emperors' authority. In addition, statues of the emperors' family such as princess Tsehaye and Ras Mokonen Wolde statues were constructed to show their lineage and thus aspired to have economic and political domination over the people who had no lineage of the aristocrats.

The second theme focuses on the colonization resistance. Most of the statues erected in the capital during the monarchial period are the result of fighting against fascist 
Italy. For instance, Yekatit 12 or Martyrs' statue, Miazi 27' or Victory statue, statue of his holiness Abune Petros, and an equestrian statue of Menelik II are some of the statues symbolize the scarification of patriotic Ethiopians and their historic victory over external invaders. Thus, the political discourses are the base for the construction almost all statues in the period Imperial Monarchy.

\subsection{Military Junta (Derg Regime)}

Derg (committee in Amharic) came to power overthrowing the imperial regime in 1974. The Derg regime came to power with the slogan of 'Land to the Tiller' and later adopted socialism as its political ideology where it pronounced the equality of all people, self-reliance, and supremacy of labor, the preeminence of the common good and the inviolability of the Ethiopian unity. Mengistu Hailemariam emerged as the undisputed leader of the Derg after the Provisional Military Administration (PMAC) (Pausewang, 1990; Aalen, 2002 and Marcus 1994).

A range of radical policies was enacted in Ethiopia during this regime. For instance, land reform which made all land in the country the property of the people was enacted. In addition, Derg changed the former language policy and recognized several widely spoken languages such as 'Afaan Oromo', 'Tigrigna', and 'Somali' for use in schools at lower levels for non-Amharic speakers. However, due to a widescale drought, and a massive refugee problem, the resistance movements spearheaded by the Eritrean People's Liberation Front (EPLF), the Tigray People's Liberation Front (TPLF), and the Oromo Liberation Front (OLF) finally brought down the military junta and established the Ethiopian People's Revolutionary Democratic Front (EPRDF) on May 28, 1991 (Bahru, 1991; Marcus, 1994; Clay and Holcomb 1986; Turton et.al, 2006).

During the reign of Derg (1974-1991), more than 40 statues that have connection with imperial monarchy regime are displaced and collected to national museum in 1976 by the order of Derg officials. Instead different statues which represent the socio-economic and political ideologies of Derg were constructed in the capital (Biniam, 2004; Meskerm, 2013). The well-known statues constructed in period are discussed below.

\section{Tiglachin or Andinet Monument}

There was geopolitical conflict between Ethiopia and Somalia during Derg regime in Ethiopia. Somali armed force incursion Ogaden and captured Jijiga in November 1977. Then, Ethiopia with help of especially Cuban military (approximately 17,000 troops with three combat brigades) scored impressive victories over Somalia (Aalen, 2002; Bahru, 2001; Tronvoll, 2009). As a result, Tiglachin monument was erected in memory of members of the heroic Ethiopian defense forces, who repulsed with Cuban support the aggressive Somali army. The monument was built at Churchill Avenue in the capital Addis Ababa but, later it was changed to Ethio-Cuba Friendship Park after the building of the monument (Addis Ababa Public and International Relations Directorate, 2011/12).

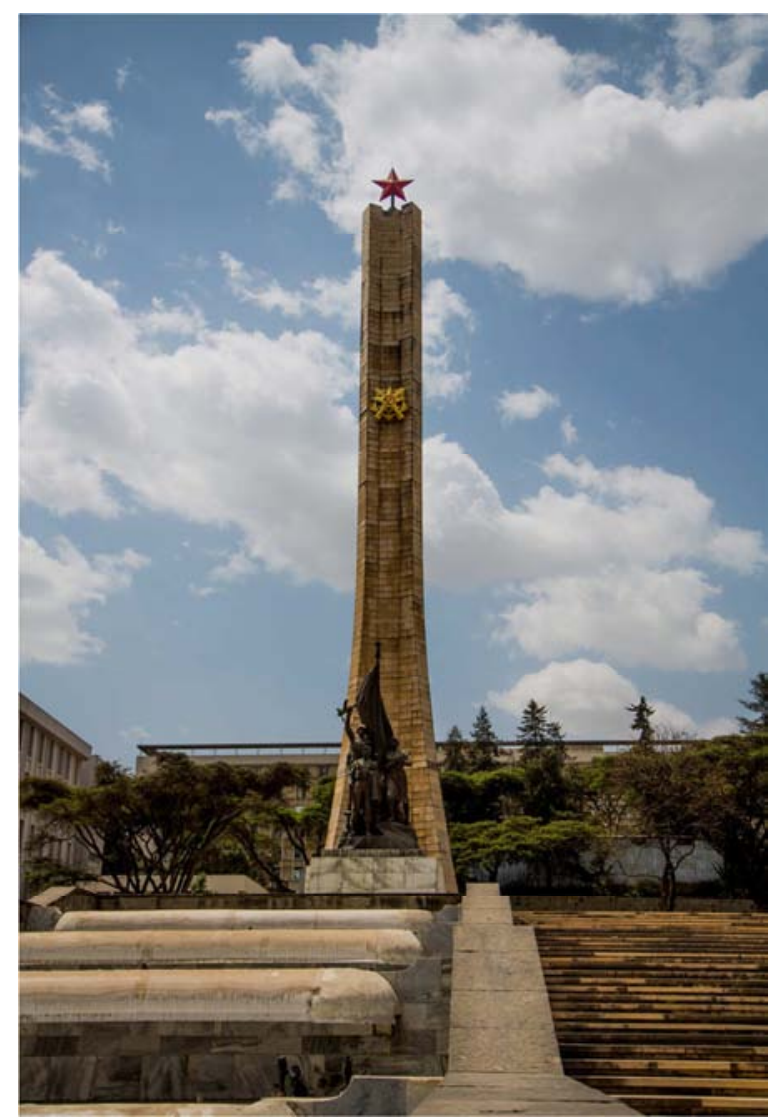

Figure 8. Tiglachin or Andinet Monumen.

\section{Monument of Vladimir Lenin and Karl Marx}

During the Derg regime, the ideology of Marxism and Leninism was a political fashion. The books of socialism pioneers especially Karl Marx and Vladimir Ilyich Lenin were ubiquitous in the country. Moreover, their statues were erected in the capital Addis Ababa to honor them (Addis Ababa Public and International Relations Directorate, 2011/12).

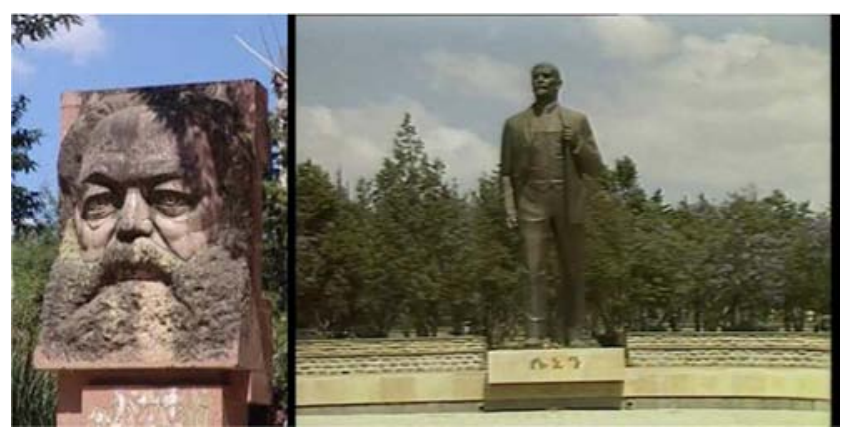

Figure 9. The Statue of Karl Mark from Left and the Statue of Lenin from Right.

\section{Statue of Alexander Pushkin}

Alexander Pushkin was a Russian poet who is his descendant family is claimed to be Ethiopian. His statue was presented from Moscow to Addis Ababa for strengthen the two cities diplomatic relationship (Biniam, 2004; Meskerm, 2013; Addis Ababa Public and International Relations Directorate, et.al, 2011/12). 


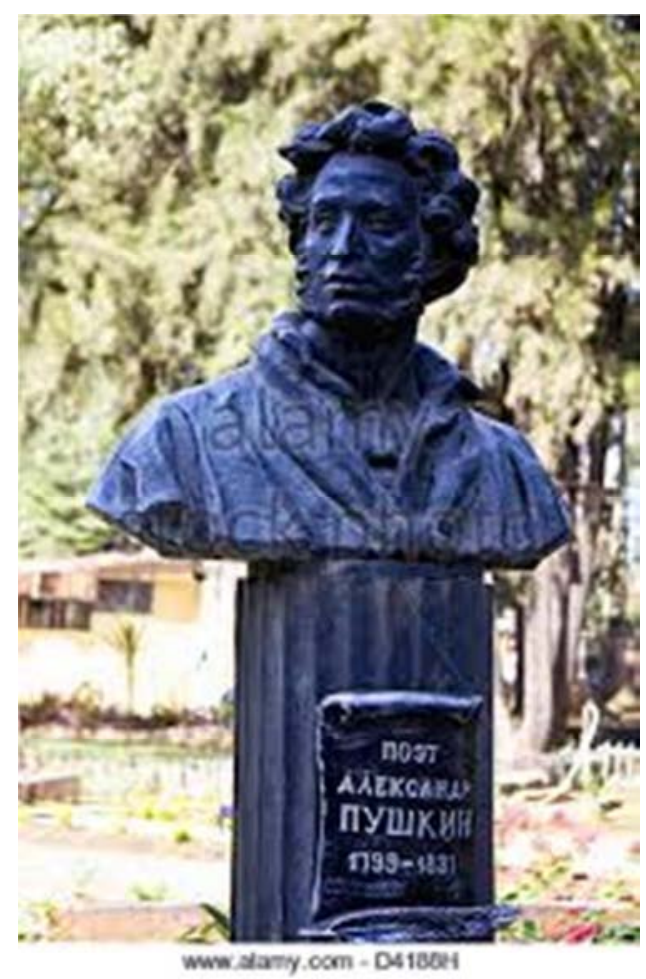

Figure 10. Statue of Alexander Pushkin.

The Statue was erected around 'Sar Bet' square in the capital and the square by itself named after the poet's name. However, the statue was displaced due to road construction and moved to the national museum.

To conclude, the period of the Derg regime in Ethiopia seems the proliferation period of statues erection where statues were highly used for a symbolic political dialog. A lot of statues constructed in the reign of imperial monarchy are displaced and destroyed during Derg regime. Instead statues that strengthen the socialism political ideology were constructed. Statues that strengthen the political relationship between Ethiopia and other socialist countries were also constructed.

\subsection{EPRDF (FDRE Regime)}

The regime of the FDRE began following the demise of the Derg regime and the coming to power of the Ethiopian People's Revolutionary Democratic Front (EPRDF) in May 1991. The EPRDF rose in response to Derg's denial of provincial and cultural autonomy. After coming to power in 1991, the EPRDF conducted Peace and Democracy conference and established Transitional Government of Ethiopia (TGE) and adopted a transitional charter which recognized freedom of association and speech, multi-party democracy, referendum for Eritrea and the right of nations, nationalities and peoples' to self- determination. In 1992, the country's internal administration was structured with the formation of 14 regional administrations along ethnolinguistic lines. After two years in 1994, the FDRE (Federal Democratic Republic of Ethiopia) constitution which recognized the right of ethnic self-determination up to secession was adopted in a view to addressing the grievances of the various ethnic groups in the country. As a result, the federal government reorganized the 14 regional states into nine regional states and two city administration cities (Assefa, 2006; Aalen, 2006; Turton, 2006; Hashim, et.al, 2010).

The federal arrangement enabled the EPRDF government to decentralize power and address nationalities question by accommodating the country's various ethno-linguistic groups. Thus, it essentially liberated different ethnic groups from the domination of one language, one culture and one religion in favor of multi-language, multi-culture and multireligion. The Constitution of the Federal Democratic Republic of Ethiopia (FDRE) also guaranteed this in Article 39 (sub-article 2) by stipulating that "every nation, nationality and people in Ethiopia has the right to speak, to write and to develop its own language; to express, to develop and to promote its culture; and to preserve its history." The political ideology of the country also shifted from socialism to multiparty democracy.

Various statues have been erected in different regional states of the country in the period of EPRDF. Majority of them are erected for the commemoration of martyrs who died in inter-political conflict between Ethiopia People Revolutionary Democratic Front (EPRDF) and the Derg military junta. The well known statues constructed in the period of EPRDF are discussed below.

\section{Red Terror Memorial Statue}

The Red Terror memorial museum built and inaugurated in 2010 around Meskel Square for martyrs who lost their life in the struggle the Derg regime for justice and democratic equality. The museum details the repressive measures taken by the Derg regime against the country at large during 1977 78. Almost 500,000 people were killed during this period (Addis Ababa Public and International Relations Directorate, 2011/12, and Meskerm, 2013).

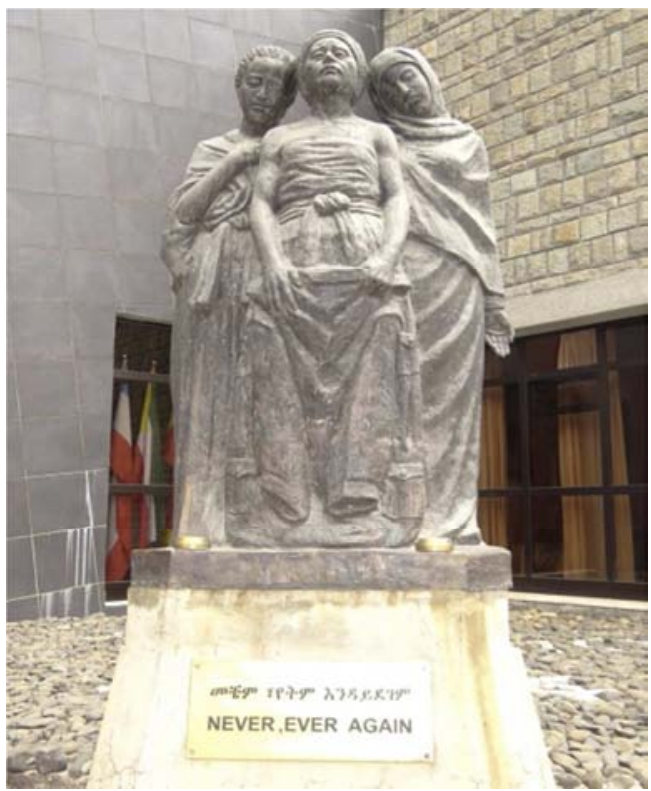

Figure 11. Red Terror Memorial Statue. 
The statue portrays a cloaked face in sorrow at the center and the rest two women's resting their heads on the woman in the center to represent family and people who lost their kin in the Red Terror. Besides, the plaque under statue reads 'Never, Ever Again' to urge not to repeat the atrocious act happened during Red Terror during the Derg regime.

\section{Oromia Region People's Martyr's Statue}

Oromoo Martyr's monument or 'Siida Waregmtoota Oromoo' was erected in Adama, city of Oromia regional state for the Oromo people who lost their life while they were struggling with Derg regime. The statue was constructed to represent many years of tranquility of the Oromo people in past political system and to commemorate the sacrifice Oromo people made during the struggle against past tyrant political leadership. In addition, the statue also depicts the bright future, hope and aspiration of the Oromo people for a better life and democratic system (Oromia Culture and Tourism Bureau, 2014)

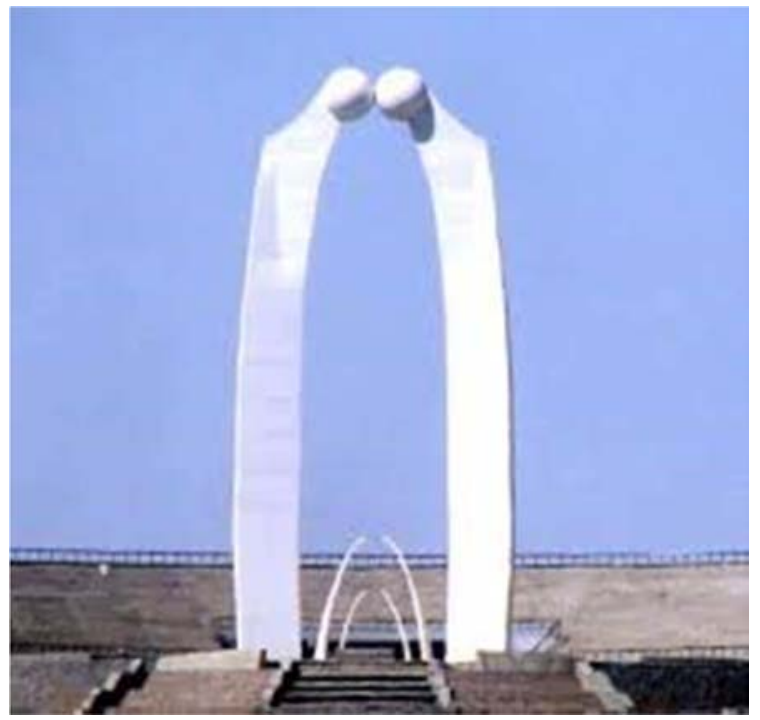

Figure 12. Oromia region People's Martry's statue at Adama City.

The monument has two main bones as major elements composing to reflect the past tranquility and the hope and promise of bright future.

III. The Tigray Region Peoples Martyr's Statue

This monument was built at Mekelle, the capital city of Tigray Regional State for the memory of those who fought to liberate their society and then the people from the dictatorial role of the Derg regime which had lasted from 1974 to 1991.

The construction of the monument was completed in 2005 by the Tigray Peoples' Liberation Front (TPLF). The statue has four massive columns which are 31 meters high from the bottom to its peak. These columns progressively come together from the stretched position at the lower part to uppermost and come together to hold the golden ball at the peak. This shows the unity of the four major political parties under EPRDF (Addis Ababa City Administration Communication Office, 2009, and Addis Ababa Public and International Relations Directorate, 2011/12).

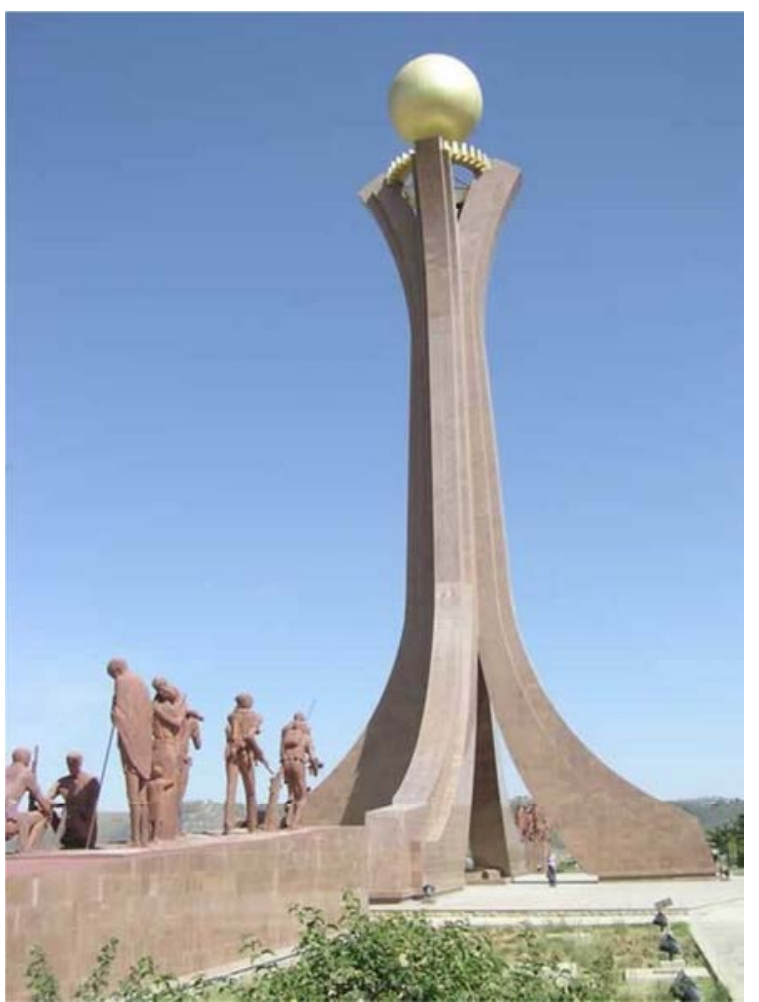

Figure 13. The Tigray Region Peoples Martyr's Statue at Mekele City.

\section{Amhara Region Peoples Martyr's Statue}

The Amhara Region Martyrs monument erected in the Bahir Dar, city of Amhara regional state to commemorate heroes and heroines who scarified their life for democracy and equality of their society.

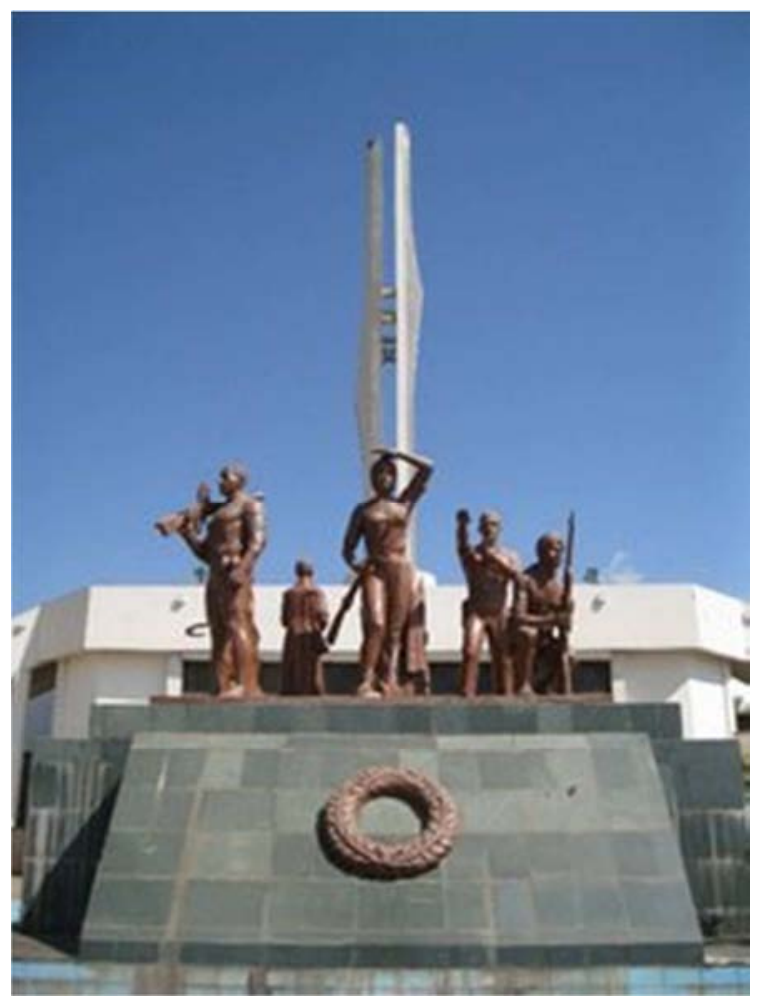

Figure 14. Amhara Region Peoples Martyr's Statue at Bahirdar City. 
The Amhara regional peoples martyr's statue has several symbolic representations. First, the statue is directly associated with the Blue Nile river to symbolize democratic struggle of the heroes to the universal nature of the river. Second, the statue is $40 \mathrm{~m}$ tall. This length represents the idea to be remembered, or to be known. Third, the statue looks like a female nature in one way and a male structure in another direction to represent the holistic struggle to be free from exploitation and economic change. Lastly, the monument is black in color in some part and white color in another. The black color used to represent the past hardship of the people while the white color shows the great hope and victory. Besides, the statue symbolizes the cultural assets of the region and the people (Addis Ababa City Administration Communication Office, 2009, and Addis Ababa Public and International Relations Directorate, 2011/12).

\section{Aanoole Martyr's Statue}

Aanolee memorial monument was erected in Hetosa, Arsi zone, Oromia region, on April 6, 2014 as a tribute to the Arsi Oromos' who were victims of the Emperor Menelik II in the processes of imperial expansion in the 1889 (Oromia Culture and Tourism Bureau, 2014). During the imperial expansion, Emporer Menelik II mutilated the hand of men and breast of women of Arsi Oromo people due to their strong resistance not to accept the rule of imperial monarchy. The statue was constructed to commemorate the past imperial yoke and horrific act happened on the Arsi Oromo and take lesson from past wrong deeds not to repeat it again (Ezikiel, 2014; Haji Abbas, 1995; Greenfield, 1965; Holcomb and Ibssa, et.al, 1990).

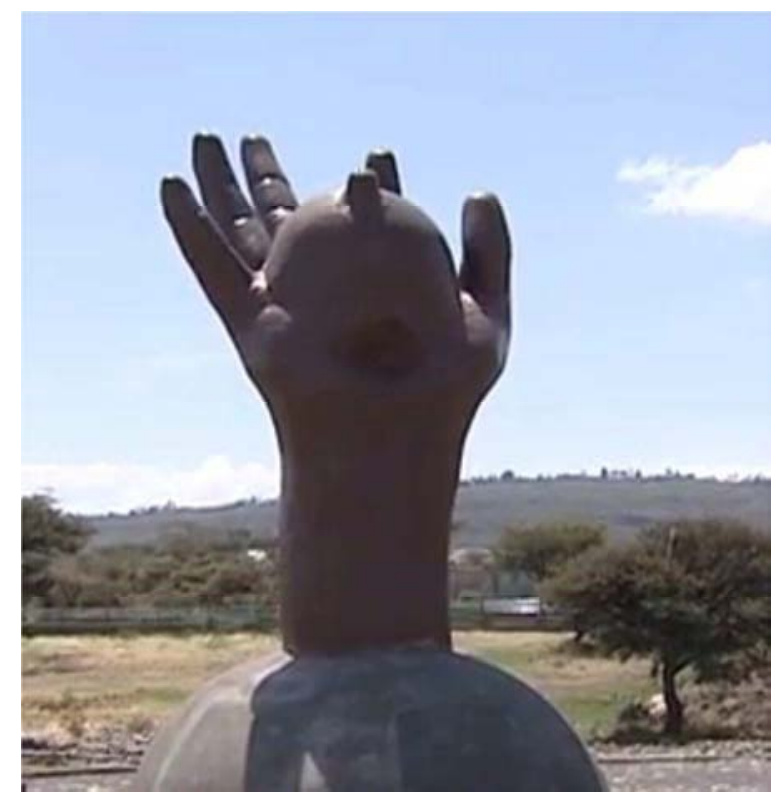

Figure 15. Aanoole Memorial Statue at Arsi Hetosa, Oromia Region.

Aanoole statue depicts the mutilated hand holding mutilated breast to represent the horrific act happened on the people of Arsi during the imperial monarchy.

To sum up, various statues constructed in the period of EPRDF that represents the struggle made by the four front coalition political parties, OPDO (Oromo Peoples' Democratic Organization), TPLF (Tigray People's Liberation Front), ANDM (Amhara National Democratic Movement) and SEPDM (Southern Ethiopian People's Democratic Movement) to overthrow the Derg dictatorship. Besides, statues that symbolize the tyrannies of monarchical period are constructed in the Ethiopia political landscape. Moreover, the normative narratives of statues erected in both former regimes (Imperial Monarchy and Derg) are counter narrated and the representation of the statues constructed in the EPRDF are become a site for public controversy and a contest for political parties.

\section{Conclusions}

People erect statues for different purposes, i.e., for spiritual significance, for the commemoration of different patriots, heroes and heroines, for the transmission of mythical histories, for representation of nation or nationalizing-state, for the preservation of cultural heritage, for beautifying cities and legitimizing authority. Moreover, statues are symbols that represent political contexts in which the society function. Their constructions are contingent on political system of the particular regime. They are used to legitimize the functioning political system in order to the public support and obey the system. In Ethiopia, different statues are erected in three consecutive regimes to depict the political system of the era. In the monarchial regimes, from Menelik II to Haile Silassie I (1889-1974) several iconic statues were constructed to glorify the emperors and at same time to legitimize the political dominance of the aristocrats over the majority peasant. Not only the statue for emperors, but the statues of emperors' family were also constructed during the monarchial period in Ethiopia. In the Derg, the military Junta (1974-1991) regime which advocates Ethiopian socialism, the statues of previous regime were dismantled, dislocated and their name were changed to denounce the monarchical regime and promote socialism in the Ethiopia. As a result, several new statues such as Marx and Lenin statues were constructed along with the socialism political manifesto. Similar to the former regimes, in the regime of FDRE (1991presnt), various statues are erected at different regional states of the country. This shows that the outcome of the federal structure that EPRDF adopts based on ethno-linguistics lines to attain the quest for political, economic and cultural autonomy of multi ethnic groups in the country. Due to this, in Bahir Dar, city of Amhara regional state, Amhara people martyrs monument is constructed for the Amhara people's martyrs. Again, in Adama and Mekelle cities, martyrs' monuments are constructed for the people of Oromo and Tigray respectively. However, some of the erected statues during the period of EPRDF are not unanimously welcomed by the society due to their representations create contention among the different ethnic based political parties found in the country. Thus, the statues erected in these three consecutive Ethiopia regimes are highly representing these regimes political system. 


\section{References}

[1] Aalen L. (2002). Ethnic Federalism in a Dominant Party State: The Ethiopian Experience 1991-2000. Norway. Chr. Michelson Institute Development Studies and Human Rights.

[2] Addis Ababa City Administration Communication Office. (2009). Lists Of Monuments in Addis Ababa. (unpublished).

[3] Addis Ababa Municipality. (1950). Mirror of Addis Ababa. Berhanina Selam printing press, Addis Ababa.

[4] Alamayo Kano. (1901). The Oromo: An Ancient People in the State Of Menelik. Finfinnee. Oromia Culture and Tourism Bureau.

[5] Armstrong P and Choudhury B. (2006). Monument and Architecture in Shaping Bangladeshi National Identity. University of Sydney. Faculty of Architecture.

[6] Assefa Fissiha. (2006). Theory Versus Practice in the Implementation Ethiopia's Ethnic Federalism. In Turton, D (ED), Ethnic Federalism: The Ethiopian Experience in Comparative Perspectives (pp 131-162). Oxford. James Currey.

[7] Bahru Zawde. (1991). A History of Modern Ethiopia, 1855 1974. London. James Currey.

[8] Bahru Zawde. (1994). The Burden of History: The constraints and Challenges of the Democratization Process in Ethiopia. Ethiopia. Addis Ababa University.

[9] Bahru, Zawde. (2001). A History of Modern Ethiopia: 1855$1991,2^{\text {nd }}(\mathrm{ed})$. Oxford. James Currey.

[10] Biiroo Oromiya Aadaafi Turizimii. (Jildii 1ffaa , Bitootessa 2006). Aadaafi Turizimii. Finfinne.

[11] Biniam Welde. (2004). Memories of the Victory of Adwa: A Focus on Its commemoration (1941-1999). (Unpublished MA thesis.) Addis Ababa University, Addis Ababa.

[12] Clay J and Holcomb B. (1986). Politics and the Ethiopian Famine. Cambridge. Mass Cultural Survival.

[13] Doresse, J. (1959). The Greatness of Ethiopia: Legends \& Reality. In UNESCO report October, 1959, Africa's Lost Past: The Startling Rediscovery of a Content (pp 30-32). France: UNESCO.

[14] Dresser, M. (2007). Set in stone? Statues and slavery in London. Retrieved on July 11, 2014 from http://belgeo.revues.org/

[15] Duerksen M. (2012). Monumentalizing Africa's Momentous Decade: Building Monuments and a Nation in Uganda. (Unpublished MA thesis.) University of Virginia.

[16] Ezekiel Gabissa. (2014). Contested Terrain: The Oromo and Ethiopian Studies. USA. Lutheran University Press.

[17] Finneran N. (2012). Lucy to Lalibela: Heritage and Identity in Ethiopia in the Twenty-First Century. International Journal of Heritage Studies, 19:1, 41-61. Retrieved on 15 May 2014 from http://dx.doi.org/10.1080/13527258.2011.633540

[18] Greenfield R. (1965). Ethiopia: A New Political History. London. PALL MALL PRESS Ltd.
[19] Grundlingh, A. M. (2001). A Cultural Conundrum? Old Monuments and New Regimes: The Voortrekker Monuments as Symbol of Afrikaner Power in a Post Apartheid South Africa. Radical History Review, Issue 81, fall 2001, pp. 95112 Published by Duke University Press. Retrieved 13 July, 2014 from http:/re/muse.jhu.edu/journals/rhr/summary/v081/ 81.1 grundlingh.html

[20] Haji Abbas Ganamo. (1995). Menelik's Conquest as the Genesis of Ethiopian Crises. A case of the Arsi Oromo. The Oromo Commentary.

[21] Hartt, F. (1989). A History of Painting. Sculpture. Architecture. New Jersey. Prentice-hall.

[22] Hashim Tewfik. (2010). Transition to Federalism: The Ethiopian Experience. Ottawa, Ontario. Forum of Federations

[23] Holcomb B and Ibssa S. (1990). The Invention of Ethiopia: The Making of a Dependent Colonial State in Northeast Africa. Trenton N. J. Red Sea Press.

[24] Jonson H. M. (1966). History of Art: A Survey of the Major Visual Arts from the Dawn of History to the Present Day. New Jersey. Prentice-hall.

[25] Larsen L. (2013). Power, Politics and Public Monuments in Nairobi, Kenya. Retrieved on July10, 2014 from $\mathrm{http}: / /$ www.opendemocracy.net

[26] Marcus H. (1994). A History of Ethiopia. Berkeley: University of California Press.

[27] McClellan Ch. (1978). Reaction to Ethiopian Expansion: The Case of Darese 1895-1913. USA. Michigan.

[28] Merera Gudina. (2003). Ethiopia: Competing Ethnic Nationalisms and the Quest for Democracy, 1960 - 2000. Addis Ababa. Chamber Printing House.

[29] Meskerm Asmamew (2013). Public Monuments of Addis Ababa 1930-1974. Addis Ababa. Goethe Institute.

[30] Pankhurst R. (1982). History of Ethiopian Towns from the middle Ages to the Early Nineteenth Century. Wiesbaden: Franz Steiner Verlag.

[31] Pausewang S. (1994). The 1994 Election and Democracy in Ethiopia. Human Rights Report Norwegian Institute of Human Rights, University of Oslo.

[32] Public and International Relations Directorate. (2011/12). Addis Ababa City of Glamorous Cultures. Addis Ababa Mayor's Office.

[33] Sorenson J. (1993). Imagining Ethiopia: Struggle for History and Identity in the Horn Africa. New Brunswick. Rutgers University Press.

[34] Tronvoll K. (2008). War \& the Politics of Identity in Ethiopia. UK. James Currey.

[35] Turton D. (2006). Ethnic Federalism: The Ethiopian Experience in Comparative Perspectives Oxford. James Currey.

[36] Whelan, Y. (2001). The construction and destruction of a colonial landscape: Monuments to British monarchs in Dublin before and after independence. Journal of Historical Geography, 28, 4 (2002) 508 \pm 533 doi:10.1006/jhge.2002.0441, available online at http://www.idealibrary.com 